\title{
Plot Size by the Variance Comparison Method for With 'Gigante' Cactus Pear
}

\author{
Bruno V. C. Guimarães ${ }^{1}$, Sérgio L. R. Donato ${ }^{2}$, Ignacio Aspiazú ${ }^{3}$, Alcinei M. Azevedo ${ }^{4}$ \& Abner J. de Carvalho ${ }^{3}$ \\ ${ }^{1}$ Departamento de Ciências Agrárias, Instituto Federal do Amazonas, São Gabriel da Cachoeira, Amazonas, \\ Brazil \\ ${ }^{2}$ Setor de Agricultura, Instituto Federal Baiano, Guanambi, Bahia, Brazil \\ ${ }^{3}$ Departamento de Ciências Agrárias, Universidade Estadual de Montes Claros, Janaúba, Minas Gerais, Brazil \\ ${ }^{4}$ Instituto de Ciências Agrárias, Universidade Federal de Minas Gerais, Montes Claros, Minas Gerais, Brazil \\ Correspondence: Bruno V. C. Guimarães, Departamento de Ciências Agrárias, Instituto Federal do Amazonas, \\ BR 307, km 03, Amazonas, CEP: 69750000, Brazil. Tel: 55-77-99121-4608. E-mail: bvinicius20@yahoo.com.br
}

Received: August 18, 2019

doi:10.5539/jas.v11n18p206
Accepted: September 19, 2019

Online Published: November 15, 2019

URL: https://doi.org/10.5539/jas.v11n18p206

\begin{abstract}
Appropriate plot size is recognized as a means of maximizing experimental accuracy and contributes to efficient treatment assessment. This study aimed to estimate the optimal plot size for experiments with 'Gigante' cactus pears using the comparison of variances method (CVM). A uniformity trial was conducted to assess plant height $(\mathrm{PH})$, number of cladodes $(\mathrm{NC})$, yield $(\mathrm{Y})$, cladode area index (CAI), cladode length $(\mathrm{CL})$, width $(\mathrm{CW})$, thickness (CT) and cladode area (CA) in a cactus pear crop. A rectangular-shaped plot consisting of 10 rows of 50 plants each was used, totaling 500 plants, with 384 basic units (BU), corresponding to the study area. A hierarchical classification approach was adopted, simulating a split-plot design in which each plant was denominated a basic unit (BU), and considering the effects of blocks $(\mathrm{B})$, plots $(\mathrm{P}) / \mathrm{B}$, subplots $(\mathrm{S}) / \mathrm{P} / \mathrm{B}$, rows $(\mathrm{R}) / \mathrm{S} / \mathrm{P} / \mathrm{B}$ and plants $(\mathrm{Pln}) / \mathrm{F} / \mathrm{S} / \mathrm{P} / \mathrm{B}$. This resulted in five plots sizes, consisting of 1, 12, 24, 48 and 96 basic units. Plots with 12, 24, 48 and $96 \mathrm{BU}$ were statistically equal for the variables $\mathrm{Y}, \mathrm{PH}, \mathrm{NC}, \mathrm{CAI}, \mathrm{CL}, \mathrm{CW}$ and $\mathrm{CT}$, with lower variances than the plot with $1 \mathrm{BU}$. As such, $4.8 \mathrm{~m}^{2}$ with 12 basic units is the optimal experimental plot size for 'Gigante' cactus pears.
\end{abstract}

Keywords: Opuntia ficus indica Mill, estimate, hierarchical model, experimental unit

\section{Introduction}

The 'Gigante' cactus pear, Opuntia ficus indica Mill, is well adapted to the conditions in Brazilian semiarid regions and an important strategic resource for animal nutrition, particularly during drought (Aguiar et al., 2015). Its high yield potential, nutritional value, drought tolerance, water use efficiency and hardiness have prompted its extensive incorporation in production arrangements and inclusion in field research (Ochoa et al., 2018; Amania et al., 2019) to better understand the plant and its potential.

In this type of research, farming experiments are the bridge between the challenges and prospects of agriculture (Sampaio Filho et al., 2019). Correct plot sizes are key to minimizing experimental error and ensuring a successful design (Facco et al., 2018), which has been established in previous studies using easy-to-apply and efficient methods (Brum et al., 2016; Guarçoni et al., 2017; Cargnelutti Filho et al., 2018).

In order to provide an effective experimental assessment, researchers must be able to statistically differentiate between treatment effects. This depends on a range of factors, including data collection, soil heterogeneity and climate conditions at the study site (Guarçoni et al., 2017). However, the appropriate plot size and number of repetitions are more important, especially when the difference between treatments is minimal.

Establishing the optimal plot size is therefore an integral part of planning and implementing an experiment, with small plots and a high number of replicates typically linked to greater accuracy when compared to large plots and few repetitions (Henriques Neto et al., 2009).

An accurate plot size helps support the experimental design for a specific crop under certain conditions, thereby preventing generalization of the estimated model. This is in line with Facco et al. (2018), who argued that plant 
behavior is significantly influenced by soil and climate factors, which can negatively affect experimental accuracy if a suboptimal plot size is used.

In this respect, the comparison of variances method (CVM) has been widely used to determine the ideal plot size for different crops (Henriques Neto et al., 2009). According to Vallejo and Mendonza (1992), CVM involves estimating the variances of different plot sizes and comparing them using Bartlett's test. The smallest plot size in a group of plot sizes with similar variances is considered the optimal size for the experiment (Ortiz, 1995).

The present study aimed to estimate the optimal plot size for experiments with 'Gigante' cactus pears using the comparison of variances method (CVM).

\section{Material and Methods}

\subsection{Experimental Design}

The trial was conducted with the 'Gigante' cactus palm (Opuntia ficus indica Mill), from 2009 to 2011, in the experimental area belonging to the Federal Institute of Bahia (IFBAIANO) at the Guanambi Campus, in Ceraíma, Bahia state, Brazil $\left(14^{\circ} 13^{\prime} 30^{\prime \prime} \mathrm{S}, 42^{\circ} 46^{\prime} 53^{\prime \prime} \mathrm{W}\right.$, altitude of $\left.525 \mathrm{~m}\right)$. The climate in the region is classified as warm tropical semiarid, according to Köppen's classification, with an average temperature of $25.9{ }^{\circ} \mathrm{C}$ and average annual rainfall of $670.2 \mathrm{~mm}$. The soil was classified as lithic neosol (EMBRAPA, 2013), with a predominantly flat relief.

Based on the principle of a uniformity trial, homogeneous treatments were applied across the entire experimental area. The soil was prepared by subsoiling, plowing, harrowing and furrow opening according to predefined row spacing. Organic fertilizer was applied in-furrow and to the topsoil before the rainy season, at 360 and 720 days after planting (DAP), using $60 \mathrm{Mg} \mathrm{ha}^{-1} \mathrm{year}^{-1}$ of fresh sheep manure. The remaining crop treatments were established in line with recommendations for forage plants under dry conditions (Ramalho et al., 2012).

The material used for planting was obtained from a cactus plantation at IFBAIANO, used for seed production. Cladodes were selected from the middle portion of the plants, based on maximum morphological similarity between the propagators. Prior to selection, the cladodes were placed in the shade for 15 days to dehydrate and allow the injuries caused by cutting to heal.

The chosen cladodes were planted $0.2 \mathrm{~m}$ apart, with $2.0 \mathrm{~m}$ between rows and the largest surface facing east-west. The experimental area was rectangular and contained 10 rows of 50 plants, totaling 500 cacti, with 384 basic units (BU) corresponding to the study area, consisting of eight rows of 48 plants each.

\subsection{Agronomic Characteristics Evaluated}

In the third production cycle, at $930 \mathrm{DAP}$, the primary cladode was used to evaluated plant height (PH-m); cladode length $(\mathrm{CL}-\mathrm{cm})$ and width $(\mathrm{CW}-\mathrm{cm})$, with graduated tape measure; cladode thickness (CT-mm), in the middle of the cladode using a digital pachymeter; number of cladodes (NC), by direct counting in the field; cladode yield $\left(\mathrm{Mg} \mathrm{ha}^{-1}\right)$, expressed by the total weight of the cladodes determined on a spring balance; cladode area and cladode area index, estimated by the equations $\left(\mathrm{CA}=\mathrm{CL} \times \mathrm{CW} \times 0.693, \mathrm{~cm}^{2}\right)$ and $\left(\mathrm{CAI}=[(\mathrm{CA} \times \mathrm{NC}) / 10,000] \times 2 ; \mathrm{m}^{2}\right)$, respectively, in line with the models adopted by Padilha et al. (2016).

\subsection{Statistical Determination}

Five plots sizes were established using different basic unit combinations, subdivided into blocks, plots, subplots, rows and plants. The plots differed in size and number of basic units, so that all of them combined filled the entire experimental area, as shown in Figure 1. 


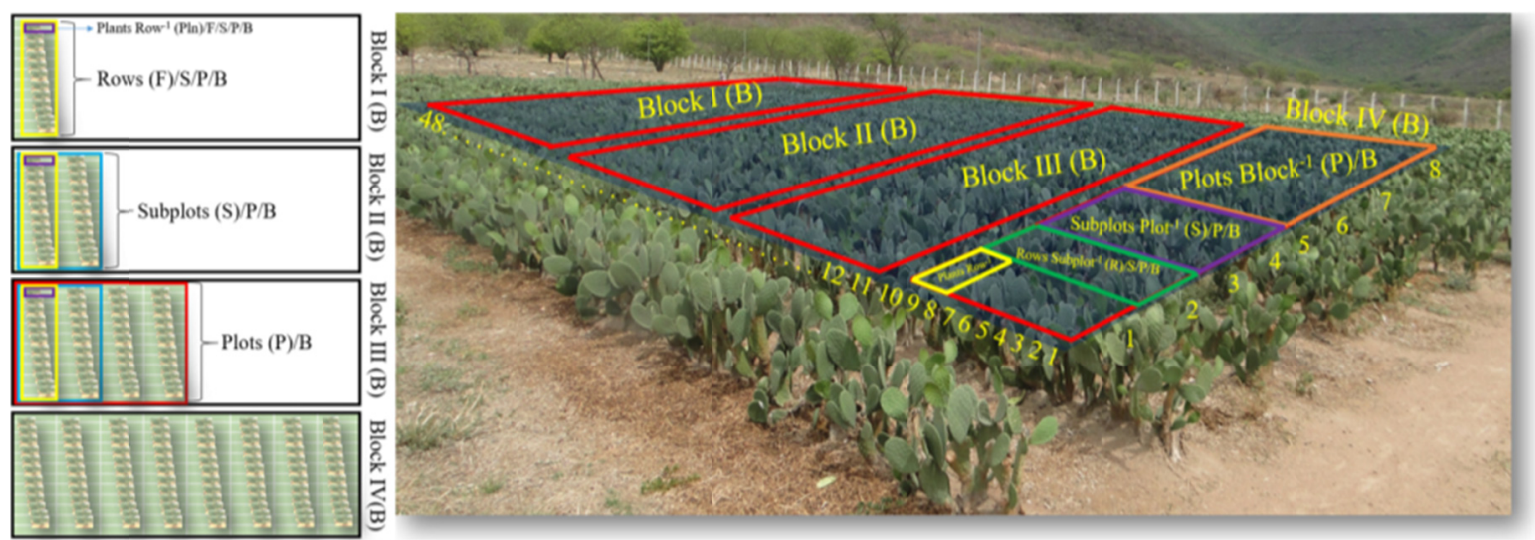

Figure 1. Schematic of the uniformity trial with 'Gigante' cactus pears, subdivided according to hierarchical classification into $(\mathrm{B})=$ blocks; $(\mathrm{P}) / \mathrm{B}=$ plots; $(\mathrm{S}) / \mathrm{P} / \mathrm{B}=$ subplots; $(\mathrm{R}) / \mathrm{S} / \mathrm{P} / \mathrm{B}=$ rows; $(\mathrm{Pln}) / \mathrm{R} / \mathrm{S} / \mathrm{P} / \mathrm{B}=$ plants

Optimal plot size was estimated based on comparison of variances, as proposed by Vallejo and Mendonza (1992). Statistical analyses were performed in $\operatorname{Excel}^{\circledR}$ (Donato et al., 2008), based on hierarchical classification, simulating a split-plot design in which each plant was denominated a basic unit (BU). Each descriptor was assessed considering the subdivisions of the study area (384 BU) into blocks (B), plots $(\mathrm{P}) / \mathrm{B}$, subplots $(\mathrm{S}) / \mathrm{P} / \mathrm{B}$, rows $(\mathrm{R}) / \mathrm{S} / \mathrm{P} / \mathrm{B})$, and plants $(\mathrm{Pln}) / \mathrm{R} / \mathrm{S} / \mathrm{P} / \mathrm{B}$ (Table 1$)$.

Table 1. Subdivisions of the plots, area, number of plots, number of basic units (BU) and number of plants in the uniformity trial with 'Gigante' cactus pears

\begin{tabular}{lllll}
\hline Subdivisions of the plots & Area $\left(\mathrm{m}^{2}\right)$ & Number of plots & Number of BU & Number of plants \\
\hline (B) & 38.4 & 4 & 96 & 96 \\
$(\mathrm{P}) / \mathrm{B}$ & 19.2 & 8 & 48 & 48 \\
$(\mathrm{~S}) / \mathrm{P} / \mathrm{B}$ & 9.6 & 16 & 24 & 24 \\
$(\mathrm{R}) / \mathrm{S} / \mathrm{P} / \mathrm{B}$ & 4.8 & 32 & 12 & 12 \\
$(\mathrm{Pln}) / \mathrm{R} / \mathrm{S} / \mathrm{P} / \mathrm{B}$ & 0.4 & 384 & 1 & 1 \\
\hline
\end{tabular}

Note. $(\mathrm{B})=$ blocks; $(\mathrm{P}) / \mathrm{B}=$ plots; $(\mathrm{S}) / \mathrm{P} / \mathrm{B}=$ subplots; $(\mathrm{R}) / \mathrm{S} / \mathrm{P} / \mathrm{B}=$ rows; $(\mathrm{Pln}) / \mathrm{R} / \mathrm{S} / \mathrm{P} / \mathrm{B}=$ plants.

Hierarchical classification resulted in five plot sizes and their respective experimental areas, consisting of 1,12 , 24,48 and $96 \mathrm{BU}$ or $0.4 ; 4.8 ; 9.6 ; 19.2 ; 38.4 \mathrm{~m}^{2}$. These were obtained by dividing the 384 study plants (basic units) into four blocks of 96 plants, then subdividing each block into two plots of 48 plants, each of these plots into two subplots of 24 plants, each subplot into two rows of 12 plants and, finally, one plant per row, as expressed in Table 1 and shown in Figure 1.

The original variances obtained with the hierarchical model were used to calculate reduced variances for the different plot sizes in basic units. Successive Bartlett tests were then performed to compare the homogeneity of variance (Steel \& Torrie, 1980), excluding in each test the smallest plot size for which variance was significantly different.

The original estimates of variance $\left(\widehat{V}_{\mathrm{i}}\right)$ for the five plot sizes, obtained by analysis of variance, were corrected based on the smallest hierarchical classification unit (1 BU), as follows:

$$
\begin{gathered}
\widehat{\mathrm{V}}_{1}^{\prime}=\widehat{\mathrm{V}}_{1} ; \\
\widehat{\mathrm{V}}_{2}^{\prime}=\frac{\left[\mathrm{e}(\mathrm{d}-1) \widehat{\mathrm{V}}_{2}+(\mathrm{e}-1) \widehat{\mathrm{V}}_{1}\right]}{[\mathrm{e}(\mathrm{d}-1)+(\mathrm{e}-1)]} ; \\
\widehat{\mathrm{V}}_{3}^{\prime}=\frac{\left[\mathrm{ed}(\mathrm{c}-1) \widehat{\mathrm{V}}_{3}+\mathrm{e}(\mathrm{d}-1) \widehat{\mathrm{V}}_{2}+(\mathrm{e}-1) \widehat{\mathrm{V}}_{1}\right]}{[\mathrm{ed}(\mathrm{c}-1)+\mathrm{e}(\mathrm{d}-1)+(\mathrm{e}-1)]} ; \\
\widehat{\mathrm{V}}_{4}^{\prime}=\frac{\left[\operatorname{edc}(\mathrm{b}-1) \widehat{V}_{4}+\mathrm{ed}(\mathrm{c}-1) \widehat{V}_{3}+\mathrm{e}(\mathrm{d}-1) \widehat{V}_{2}+(\mathrm{e}-1) \widehat{V}_{1}\right]}{[\operatorname{edc}(\mathrm{b}-1)+\mathrm{ed}(\mathrm{c}-1)+\mathrm{e}(\mathrm{d}-1)+(\mathrm{e}-1)]} ; \\
\widehat{\mathrm{V}}_{5}^{\prime}=\frac{\left[\operatorname{edcb}(\mathrm{a}-1) \widehat{\mathrm{V}}_{5}+\operatorname{edc}(\mathrm{b}-1) \widehat{\mathrm{V}}_{4}+\operatorname{ed}(\mathrm{c}-1) \widehat{\vee}_{3}+\mathrm{e}(\mathrm{d}-1) \widehat{\mathrm{V}}_{2}+(\mathrm{e}-1) \widehat{\mathrm{V}}_{1}\right]}{[\operatorname{edcb}(\mathrm{a}-1)+\operatorname{edc}(\mathrm{b}-1)+\operatorname{ed}(\mathrm{c}-1)+\mathrm{e}(\mathrm{d}-1)+(\mathrm{e}-1)]}
\end{gathered}
$$


where, $\widehat{V}_{i}$ is the original variance; $\widehat{V}_{i}^{\prime}$ corrected variance; a, number of plants per row; $b$, number of rows per subplots; c, number of subplots per plot; $d$, number of plots per block, and e, the number of blocks.

The reduced variances $\widehat{V}_{(\mathrm{xi})}$ in relation to one basic unit (plant) were calculated by dividing the corrected variances $\left(\widehat{V}_{\mathrm{i}}^{\prime}\right)$ of the different plot sizes by their respective numbers of basic units, as shown in the equations below:

$$
\widehat{\mathrm{V}}_{\mathrm{x}=15}=\frac{\widehat{\mathrm{V}}_{3}^{\prime}}{15} ; \widehat{\mathrm{V}}_{(\mathrm{x}=5)}=\frac{\widehat{\mathrm{V}}_{4}^{\prime}}{5} ; \widehat{\mathrm{V}}_{(\mathrm{x}=1)}=\widehat{\mathrm{V}}_{5}^{\prime}
$$

\section{Results and Discussion}

Variances exhibited random behavior according to the characteristic analyzed and the plot size used (Table 2). Thus, as expected, the largest assessment unit (block) or smallest basic unit (one plant) did not necessarily exhibit the smallest and lowest variances, respectively (Table 2).Furthermore, Lorentz et al. (2012) found that these parameters can be influenced by soil heterogeneity or the characteristic studied, since they are reflections of the coefficients of variation between adjacent plots.

Table 2. Analysis of variance as a function of the hierarchical classification criterion adopted for phenotypic descriptors in 'Gigante' cactus pears

\begin{tabular}{|c|c|c|c|c|c|c|c|c|c|c|}
\hline \multirow{2}{*}{ Source of variation } & \multirow{2}{*}{ DF } & \multirow{2}{*}{$\mathrm{X}(\mathrm{BU})$} & \multicolumn{2}{|c|}{ Plant height } & \multicolumn{2}{|c|}{ Cladode area index } & \multicolumn{2}{|c|}{ Number of cladodes } & \multicolumn{2}{|c|}{ Yield } \\
\hline & & & $\mathrm{Vi}$ & $\mathrm{Vi}^{\prime}$ & $\mathrm{Vi}$ & $\mathrm{Vi}^{\prime}$ & $\mathrm{Vi}$ & $\mathrm{Vi}^{\prime}$ & $\mathrm{Vi}$ & $\mathrm{Vi}^{\prime}$ \\
\hline (B) & 3 & 96 & 0.1668 & 0.1668 & 0.3535 & 0.3535 & 107.4271 & 107.4271 & 43529.7906 & 453.4353 \\
\hline$(\mathrm{P}) / \mathrm{B}$ & 4 & 48 & 0.0648 & 0.1085 & 0.3510 & 0.3521 & 140.7396 & 126.4628 & 16077.1647 & 580.0537 \\
\hline$(\mathrm{S}) / \mathrm{P} / \mathrm{B}$ & 8 & 24 & 0.1781 & 0.1456 & 0.8210 & 0.6022 & 302.9063 & 220.5660 & 101714.9902 & 2801.7165 \\
\hline$(\mathrm{F}) / \mathrm{S} / \mathrm{P} / \mathrm{B}$ & 16 & 12 & 0.0643 & 0.1036 & 0.2237 & 0.4068 & 50.0208 & 132.5427 & 14704.1178 & 3343.7738 \\
\hline$(\mathrm{Pln}) / \mathrm{F} / \mathrm{S} / \mathrm{P} / \mathrm{B}$ & 352 & 1 & 0.0443 & 0.0491 & 0.2638 & 0.2754 & 53.0473 & 59.4817 & 22850.7827 & 24248.980 \\
\hline \multirow{2}{*}{ Source of variation } & \multirow{2}{*}{ DF } & \multirow{2}{*}{$\mathrm{X}(\mathrm{BU})$} & \multicolumn{2}{|c|}{ Cladode area } & \multicolumn{2}{|c|}{ Cladode length } & \multicolumn{2}{|c|}{ Cladode thickness } & \multicolumn{2}{|c|}{ Cladode width } \\
\hline & & & $\mathrm{Vi}$ & $\mathrm{Vi}^{\prime}$ & $\mathrm{Vi}$ & $\mathrm{Vi}^{\prime}$ & $\mathrm{Vi}$ & $\mathrm{Vi}^{\prime}$ & $\mathrm{Vi}$ & $\mathrm{Vi}^{\prime}$ \\
\hline (B) & 3 & 96 & 112.2353 & 112.2353 & 0.8079 & 0.8079 & 179.0528 & 179.0528 & 0.3483 & 0.3483 \\
\hline$(\mathrm{P}) / \mathrm{B}$ & 4 & 48 & 1990.2374 & 1185.3794 & 7.8764 & 4.8471 & 125.4161 & 148.4032 & 1.9749 & 1.2778 \\
\hline$(\mathrm{S}) / \mathrm{P} / \mathrm{B}$ & 8 & 24 & 5888.8964 & 3693.9218 & 11.6323 & 8.4658 & 126.8962 & 136.9328 & 5.0900 & 3.3110 \\
\hline$(\mathrm{F}) / \mathrm{S} / \mathrm{P} / \mathrm{B}$ & 16 & 12 & 2895.4228 & 3281.7933 & 7.1693 & 7.7967 & 43.8829 & 88.9070 & 2.4431 & 2.8630 \\
\hline$(\mathrm{P} \ln ) / \mathrm{F} / \mathrm{S} / \mathrm{P} / \mathrm{B}$ & 352 & 1 & 1631.8460 & 1765.3927 & 3.9069 & 4.2217 & 9.6705 & 16.0839 & 1.2409 & 1.3722 \\
\hline
\end{tabular}

Note. Degree of freedom (DF); Plot size in basic units (X-BU) Blocks (B); Plots/Blocks (P)/B; Subplots/Plots (S)/P/B; Rows/Subplots (R)/S/P/B; Plants/Rows (Pln)/R/S/P/B; Vi' (corrected); V (reduced).

Analysis of the coefficients of variation (CV) associated with the five plot sizes demonstrated that the hierarchical increase in plot size significantly reduced the CV values of all the characteristics assessed, representing an inverse relationship between the statistical parameter (CV) and its respective plot sizes (Table 3). Similar results were reported by Vallejo and Mendonza (1992), Viana et al. (2002), Donato et al. (2008) and Henriques Neto et al. (2009) in sweet potato, cassava, banana and wheat, respectively.

Table 3. Estimated coefficients of variation (\%) for the different plot sizes and characteristics of 'Gigante' cactus pears

\begin{tabular}{llllllllll}
\hline \multirow{2}{*}{ Area $\left(\mathrm{m}^{2}\right)$} & \multirow{2}{*}{$\mathrm{X}(\mathrm{BU})$} & \multicolumn{9}{c}{ Coefficient of Variation (\%) } \\
\cline { 3 - 10 } & & PH & CAI & YLD & NC & CA & CL & CT & CW \\
\hline 0.4 & 1 & 18.82 & 40.13 & 49.92 & 36.58 & 13.63 & 6.91 & 47.63 & 8.05 \\
4.8 & 12 & 7.93 & 14.33 & 19.00 & 15.96 & 5.35 & 2.68 & 19.68 & 3.36 \\
9.6 & 24 & 6.66 & 12.25 & 17.42 & 14.50 & 4.02 & 1.98 & 17.30 & 2.55 \\
19.2 & 48 & 4.20 & 6.55 & 7.20 & 7.70 & 1.65 & 1.07 & 12.86 & 1.13 \\
38.4 & 96 & 3.62 & 4.65 & 6.06 & 5.05 & 0.50 & 0.30 & 10.06 & 0.46 \\
\hline
\end{tabular}

Note. Plot size in basic units (X-BU), plant height $(\mathrm{PH})$, cladode area index (CAI), yield (YLD), number of cladodes $(\mathrm{NC})$, cladode area (CA), cladode length (CL), cladode thickness $(\mathrm{CT})$ and cladode width $(\mathrm{CW})$. 
Coefficients of variation ranged between 0.30 and $49.92 \%$ as a function of the specificity of the characteristic assessed, with the highest variations related to yield and the lowest to cladodes, such as cladode area (CA), width (CW) and length (CL), with the exception of cladode thickness (CT). This is because CT is heavily dependent on the stage of vegetative growth (Silva et al., 2015) and directly related to the photosynthetic capacity and moisture content of the cladode (Scalisi et al., 2016), exhibiting high agronomic variability (Table 3 ).

The CV values of the plot sizes assessed were inversely proportional to plot size. These findings are similar to those reported in several studies on experimental planning, regardless of the crop analyzed or method used (Viana et al., 2002; Donato et al., 2008; Brum et al., 2016; Guarçoni et al., 2017; Cargnelutti Filho et al., 2018).

Thus, based on the afore mentioned studies on plot size, it can be inferred that a rise in plot size leads to a decline in the coefficient of variation. This occurs primarily when the soil heterogeneity index (SHI) is high, as observed in the present study, where SHI was greater than 0.7 for all the characteristics analyzed except CT, which exhibited an average value of 0.45 . As such, although SHI is not estimated or discussed in this study, it is important to note that under soil conditions with SHI $>0.7$, an increase in plot size is more effective at minimizing the influence of soil heterogeneity in the experimental area than raising the number of repetitions (Donato et al., 2018).

Based on the comparison of variances method substantiated by Bartlett's test, Table 4 indicates that the reduced variances were higher in plots with one BU, a finding inherent to the method and corroborated by other studies (Vallejo \& Mendoza, 1992). Additionally, Lúcio et al. (2004), Lopes et al. (2005), Donato et al. (2008), Henriques Neto et al. (2009) and Lorentz et al. (2012) confirmed the existence of an inverse relationship between plot sizes and their respective variances, reinforcing the importance of determining the optimal plot size.

Table 4. Estimated reduced variances, in basic units (BU), for the different plot sizes and characteristics of 'Gigante' cactus pears

\begin{tabular}{llllllllll}
\hline \multirow{2}{*}{ Area $\left(\mathrm{m}^{2}\right)$} & \multirow{2}{*}{$\mathrm{X}(\mathrm{BU})$} & \multicolumn{8}{c}{ Reduced variance $\mathrm{V}\left(\mathrm{x}_{\mathrm{i}}\right)$} \\
\cline { 3 - 9 } & & PH & CAI & YLD & NC & CA & CL & CT & $\mathrm{CW}$ \\
\hline 0.4 & 1 & $0.0491 \mathrm{a}$ & $0.2754 \mathrm{a}$ & $24248.9800 \mathrm{a}$ & $59.4817 \mathrm{a}$ & $1765.3927 \mathrm{a}$ & $4.2217 \mathrm{a}$ & $73.4358 \mathrm{a}$ & $1.3722 \mathrm{a}$ \\
4.8 & 12 & $0.0086 \mathrm{~b}$ & $0.0339 \mathrm{~b}$ & $3343.7738 \mathrm{~b}$ & $11.0452 \mathrm{~b}$ & $273.4828 \mathrm{~b}$ & $0.6497 \mathrm{~b}$ & $8.5478 \mathrm{~b}$ & $0.2386 \mathrm{~b}$ \\
9.6 & 24 & $0.0061 \mathrm{~b}$ & $0.0251 \mathrm{~b}$ & $2801.7165 \mathrm{~b}$ & $9.1902 \mathrm{~b}$ & $153.9134 \mathrm{~b}$ & $0.3527 \mathrm{~b}$ & $4.2037 \mathrm{~b}$ & $0.1380 \mathrm{~b}$ \\
19.2 & 48 & $0.0023 \mathrm{~b}$ & $0.0073 \mathrm{~b}$ & $580.0537 \mathrm{~b}$ & $2.6346 \mathrm{~b}$ & $24.6954 \mathrm{~b}$ & $0.1010 \mathrm{~b}$ & $2.1717 \mathrm{~b}$ & $0.0266 \mathrm{~b}$ \\
38.4 & 96 & $0.0017 \mathrm{~b}$ & $0.0037 \mathrm{~b}$ & $453.4353 \mathrm{~b}$ & $1.1190 \mathrm{~b}$ & $1.1691 \mathrm{c}$ & $0.0084 \mathrm{~b}$ & $1.3908 \mathrm{~b}$ & $0.0036 \mathrm{~b}$ \\
\hline
\end{tabular}

Note. Plot size in basic units (X-BU), plant height $(\mathrm{PH})$, cladode area index (CAI), yield (YLD), number of cladodes (NC), cladode area (CA), length (CL), thickness (CT) and width (CW). The same letters exhibited no significant differences according to Bartlett's test.

This behavior was observed for all the characteristics analyzed, with specificity for CA, whereby plots consisting of 12, 24 and $48 \mathrm{BU}$ displayed higher variances than the plot with one $\mathrm{BU}$ and lower variances than that with 96 $\mathrm{BU}$, which were statistically equal. In this case, despite its high variance, the plot size consisting of $96 \mathrm{BU}$ is ideal for experimental assessment of $\mathrm{CA}$, but would require weighting since it exceeds the optimal size for most of the variables studied by $84 \mathrm{BU}$.

For the remaining variables, plots containing $12,24,48$ and $96 \mathrm{BU}$ were statistically equal, with lower variances than those recorded in the plot with $1 \mathrm{BU}$. As such, a plot consisting of $12 \mathrm{BU}\left(4.8 \mathrm{~m}^{2}\right)$ was considered the optimal size for experiments with 'Gigante' cactus pears because variance did not decline significantly when larger plot sizes were used (Table 4).

Additionally, in accordance with Table 4, comparison of variances can only estimate plot sizes that coincide with the sizes in basic units predefined by the model, meaning intermediate values between BU cannot be considered.

This same limitation was highlighted by Viana et al. (2002) and Donato et al. (2008) for CVM as well as the maximum curvature and modified maximum curvature methods. The comparison of variances method also exhibited limited cost effectiveness for field experiments, as observed by Guarçoni et al. (2017), who found that it restricted response plateau models.

However, when field experiments are based on accurate plot sizes, cost parameters can largely be disregarded in favor of reducing error and maximizing accuracy, unless the amounts involved are excessive (Viana et al., 2002). 
The descriptors assessed here are frequently included in experiments with 'Gigante' cactus pears, making it relevant to establish an optimal plot size to analyze them accurately. Thus, since the optimal plot size for most of the characteristics was $12 \mathrm{BU}$ or $4.8 \mathrm{~m}^{2}$, this can be considered the most appropriate size for experiments with 'Gigante' cactus pears.

It is important to note that an optimal parcel size ensures efficient data collection in these plants, since their spines and irregular growth can make it difficult to obtain measurements in the field when plots are large, leading to potential errors. As such, this study provides researchers with the appropriate plot size for field experiments.

\section{Conclusions}

Plots measuring $4.8 \mathrm{~m}^{2}$ with 12 basic units are the ideal size for experiments with 'Gigante' cactus pears.

\section{References}

Aguiar, M. S. M. A., Siva, F. F., Donato, S. L. R., Schio, A. R., Souza, D. D., Meneses, M. A., \& Lédo, A. A. (2015). Síntese de proteína microbiana e concentração de ureia em novilhas leiteiras alimentadas com palma forrageira Opuntia. Semina: Ciências Agrárias, 36(2), 999-1012. https://doi.org/10.5433/1679-0359.2015 v36n2p999

Amania, E., Marwa, L., Hichem, B. S., Amel, S. H., \& Ghada, B. (2019). Morphological variability of prickly pear cultivars (Opuntia spp.) established in ex-situ collection in Tunisia. Scientia Horticulturae, 248(5), 163-175. https://doi.org/10.1016/j.scienta.2019.01.004

Brum, B., Brandelero, F. D., Vargas, T. de O., Storck, L., \& Zanini, P. P. G. (2016). Tamanho ótimo de parcela para avaliação da massa e diâmetro de cabeças de brócolis. Ciência Rural, 46(3), 447-463. https://doi.org/ $10.1590 / 0103-8478 \mathrm{cr} 20150236$

Cargnelutti Filho, A., Araújo, M. M., Gasparin, E., \& Foltz, D. R. B. (2018). Dimensionamento amostral para avaliação de altura e diâmetro de plantas de timbaúva. Floresta e Ambiente, 25(1), 1-9. https://doi.org/ $10.1590 / 2179-8087.121314$

Donato, S. L. R., Siqueira, D. L., Silva, S. de O., Cecon, P. R., Silva, J. A., \& Salomão, L. C. C. (2008). Estimativas de tamanho de parcelas para avaliação de descritores fenotípicos em bananeira. Pesquisa Agropecuária Brasileira, 43(8), 957-969. https://doi.org/10.1590/S0100-204X2008000800003

Donato, S. L. R., Silva, J. A. da, Guimarães, B. V. C., \& Silva, S. de O. (2018). Experimental planning for the evaluation of phenotipic descriptors in banana. Revista Brasileira Fruticultura, 40(5), 1-13. https://doi.org/ 10.1590/0100-29452018962

EMBRAPA (Empresa Brasileira de Pesquisa Agropecuária). (2013). Sistema brasileiro de classificação de solos (p. 353, 3rd ed.). Brasília: Embrapa Informação Tecnológica.

Facco, G., Cargnelutti Filho, A., Lavezo, A., Schabarum, D. E., Chaves, G. G., \& Silveira, D. L. (2018). Basic experimental unit and plot sizes for fresh matter of sunn hemp. Ciência Rural, 48, e20170660. https://doi.org/10.1590/0103-8478cr20170660

Guarçoni, R. C., Souza, J. L de, Favarato, L. F., Angeletti, M. da P., \& Bahiense, D. V. (2017). Determinação do tamanho ótimo de parcela experimental para experimentos com repolho utilizando simulação e métodos de estimação. Revista Científica Intelletto, 2(2), 79-87. https://doi.org/10.17648/intelletto-2525-9075-v2-n2-09

Henriques Neto, D., Sediyama, T., Souza, M. A., Leite, L. F. C., \& Blanco, F. F. (2009). Tamanho de parcela para avaliação da produção em trigo irrigado, sob dois sistemas de plantio. Revista Ciência Agronômica, 40(1), 86-93. Retrieved from https://www.embrapa.br/busca-de-publicacoes/-/publicacao/71094/tamanho-deparcela-para-avaliacao-da-producao-em-trigo-irrigado-sob-dois-sistemas-de-plantio

Lopes, S. J., Storck, L., Lúcio, A. D., Lorentz, L. H., Lovato, C., \& Dias, V. O. (2005). Tamanho de parcela para produtividade de grãos de sorgo granífero em diferentes densidades de plantas. Pesquisa Agropecuária Brasileira, 40(6), 525-530. https://doi.org/10.1590/S0100-204X2005000600001

Lorentz, L. H., Erichsen, R., \& Lúcio, A. D. (2012). Proposta de método para estimação de tamanho de parcela para culturas agrícolas. Revista Ceres, 59(6), 772-780. https://doi.org/10.1590/S0034-737X2012000600006

Lúcio, A. D., Mello, R. M., Storck, L., Carpes, R. H., Boligon, A. A., \& Zanardo, B. (2004). Estimativa de parâmetros para o planejamento de experimentos com a cultura do pimentão em área restrita. Horticultura Brasileira, 22(4), 766-770. https://doi.org/10.1590/S0102-05362004000400020 
Ochoa, G. O., Caratachea, A. J., Sánchez, R. E. P., Flores, H. E. M., Cordova, J. E., \& Rodríguez, R. O. (2018). Effect of lactating sows' diet supplemented with cactus (Opuntia ficus-indica) on feed intake and reproductive and productive post-weaning performances. Tropical Animal Health and Production, 1, 1-12. https://doi.org/10.1007/s11250-018-1611-X

Ortiz, R. (1995). Plot techniques for assessment of bunch weight in banana trials under two systems of crop management. Agronomy Journal, 87(1), 63-69. https://doi.org/10.2134/agronj1995.000219620087000 $10011 x$

Padilha Junior, M. C., Donato, S. L. R., Silva, J. A. da, Donato, P. E. R., \& Souza, E. S. (2016). Características morfométricas e rendimento da Palma forrageira 'Gigante' sob diferentes adubações e configurações de plantio. Revista Verde de Agroecologia e Desenvolvimento Sustentável, 11(1), 67-72. https://doi.org/ 10.18378/rvads.v11i1.3710

Ramalho, M. A. P., Ferreira, D. F., \& Oliveira, A. C. de. (2012). Experimentação em genética e melhoramento de plantas (p. 305). Lavras: Editora da UFLA.

Sampaio Filho, O. M., Silva, S. de O., Donato, S. L. R., Silva, S. A., \& Silva, M. dos S. da. (2019). Optimum experimental plot size in the castor bean. Revista Ciência Agronômica, 50(2), 276-281. https://doi.org/ $10.5935 / 1806-6690.20190032$

Scalisi, A., Morandi, B., Inglese, P., \& Bianco, R. L. (2016). Cladode growth dynamics in Opuntia ficus-indica under drought. Environmental and Experimental Botany, 122(1), 158-167. https://doi.org/10.1016/ j.envexpbot.2015.10.003

Silva, T. G. F. da, Primo, J. T. A., Morais, J. E. F. de, Diniz, W. J. da S., Souza, C. A. A. de, \& Silva, M. da C. (2015). Crescimento e produtividade de clones de Palma forrageira no semiárido e relações com variáveis meteorológicas. Revista Caatinga, 28(2), 10-18. Retrieved from https://periodicos.ufersa.edu.br/index.php/ caatinga/article/view/3630/pdf_241

Steel, R. G. D., \& Torrie, J. H. (1980). Principles and procedures of statistics (p. 633, 2nd ed.). New York: McGraw-Hill Book.

Vallejo, R. L., \& Mendoza, H. A. (1992). Plot technique studies on sweet potato yield trials. Journal of the American Society for Horticultural Science, 117(3), 508-511. https://doi.org/10.21273/JASHS.117.3.508

Viana, A. E. S., Sediyama, T., Cecon, P. R., Lopes, S. C., \& Sediyama, M. A. N. (2002). Estimativas de tamanho de parcela em experimentos com mandioca. Horticultura Brasileira, 20(1), 58-63. https://doi.org/10.1590/ S0102-05362002000100011

\section{Copyrights}

Copyright for this article is retained by the author(s), with first publication rights granted to the journal.

This is an open-access article distributed under the terms and conditions of the Creative Commons Attribution license (http://creativecommons.org/licenses/by/4.0/). 